\title{
Soil carbon, nitrogen and phosphorus in modified rangeland communities
}

\author{
JOANN K. WHALEN, WALTER D. WILLMS AND JOHAN F. DORMAAR
}

Authors are Assistant Professor, Department of Natural Resource Science and McGill School of Environment, Macdonald Campus of McGill University, 21,111 Lakeshore Road, Ste. Anne de Bellevue, Quebec, Canada, H9X 3V9; and Range Ecologist and Soil Scientist (retired), Research Centre, Agriculture and Agri-Food Canada, P.O. Box 3000, Lethbridge, Alberta, Canada, T1J 4B1. At the time of the research, the senior author was Research Scientist (term), Agriculture and Agri-Food Canada, Lethbridge, Alberta.

\section{Abstract}

Rangelands contain between 10 and $30 \%$ of global soil organic $\mathrm{C}$ reserves and may be an important sink for atmospheric $\mathrm{CO}_{2}$, but less $\mathrm{C}$ tends to be stored in rangelands cultivated for agricultural use than undisturbed rangelands. Establishing perennial plant communities on formerly cultivated rangelands is expected to stabilize soil properties and increase the amount of $\mathbf{C}$ stored in rangeland soils, but there is little information on what plant communities are most effective at building soil $\mathrm{C}$ reserves. The purpose of this study was to compare soil $C, N$, and $P$ pools in ungrazed native rangelands with ungrazed, unfertilized rangelands that were cultivated and then 1) abandoned, 2) seeded with non-native perennial grasses or legumes, or 3) cropped annually for 5 to 6 years. Three study sites in southern Alberta, Canada with native Stipa-Bouteloua, Stipa-Bouteloua-Agropyron and Festuca campestris plant communities represented the major ecotypes of the Northern Great Plains. The total $C, N$, and $P$ content of rangeland soils were greatest at the Festuca campestris site, followed by the Stipa-Bouteloua-Agropyron and Stipa-Bouteloua sites, probably due to climatic conditions (precipitation and temperature). Generally, soils under modified plant communities contained less total $\mathbf{C}$ and $\mathbf{N}$ than soils under native rangeland, but the total $P$ content was related more to site preparation than experimental treatments. Soils under alfalfa, orchardgrass and bromegrass tended to have more total $\mathrm{C}$ and $\mathrm{N}$ than soils cultivated annually in continuous wheat or wheat-fallow systems. The accumulation of $C$ and $N$ in soils under permanent cover was not related to net primary productivity and may be influenced more by the chemical composition and rate of decomposition of plant residues.

Key Words: cultivated, introduced grasses, alfalfa, native rangeland, total nutrients, extractable nutrients

Grazing lands contain an estimated 10 to $30 \%$ of the world's soil organic $\mathrm{C}$ and, depending on how they are managed, have the potential to act as a significant sink of atmospheric $\mathrm{CO}_{2}$ (Schuman et al. 2002, Lal 2002). A considerable portion of the rangeland in the Great Plains of North America was cultivated for agricultural use in the last $100+$ years, causing a 24 to $60 \%$ reduction in the soil organic C pool (Gebhart et al. 1994). Intense culti-

Authors wish to thank S. Foran, J. Carefoot, and M. Crowe assistance with soil sampling and laboratory analysis.

Manuscript accepted 20 Jan. 2003.
Resumen

Los pastizales contienen entre 10 y $30 \%$ de las reservas globales de $\mathrm{C}$ orgánico del suelo y pueden ser un importante depósito para el $\mathrm{CO}_{2}$ atmosférico, pero menos carbón tiende a ser almacenado en los pastizales cultivados para fines agrícolas que en los pastizales sin disturbio. Se espera que el establecimiento de comunidades vegetales perennes en las tierras cultivadas que primeramente fueron pastizales estabilice las propiedades del suelo e incremente la cantidad de $\mathbf{C}$ almacenado en los suelos de pastizal, pero hay poca información sobre cuales comunidades de plantas son mas efectivas en crear las reservas de $\mathbf{C}$ del suelo. El objetivo de este estudio fue comparar las reservas de $C, N$ y $P$ en pastizales nativos sin apacentamiento contra pastizales sin apacentamiento ni fertilización que fueron cultivados y luego: 1) abandonados, 2) sembrados con especies de zacates perennes o leguminosas no nativos y 3) cultivados anualmente por 5 o 6 años. El estudio se desarrollo en tres sitios en el sur de Alberta, Canada con comunidades de plantas nativas de Stipa-Bouteloua, Stipa-Bouteloua-Agropyron y Festuca campestris que representaron los principales ecotipos de las Grandes Planicies del Norte. El contenido total de $\mathbf{C}, \mathbf{N}, \mathbf{y} P$ de los suelos de pastizal fue mayor en el sitio de Festuca campestris, seguido por los sitios de StipaBouteloua-Agropyron y Stipa-Bouteloua, probablemente debido a las condiciones climáticas (precipitación y temperatura). Generalmente los suelos bajo comunidades de plantas modificadas contuvieron menos $\mathbf{C}$ y $\mathbf{N}$ total que los suelos de pastizal nativo, pero el contenido total de $\mathbf{P}$ se relaciono mas a la preparación del sitio que a los tratamientos experimentales. Los suelos con alfalfa, "Orchardgrass" y "Bromegrass"tendieron a tener mas $\mathbf{C}$ y $\mathbf{N}$ total que los suelos cultivados anualmente con los sistemas trigo continuo o trigo-descanso. La acumulación de $\mathrm{C}$ y $\mathbf{N}$ en suelos con cubierta permanente no estuvo relacionada con la productividad primaria neta y puede estar influenciado mas por la composición química y la tasa de descomposición de los residuos de plantas.

vation (i.e., moldboard plowing) disrupts soil aggregates and fragments organic matter, accelerating decomposition, increasing microbial activity and stimulating the emission of $\mathrm{CO}_{2}$ from soils (Anderson and Coleman 1985, Burke et al. 1995). The $C$ input from agricultural crops is generally lower than from rangeland plant communities because more of the above-ground biomass may be removed from the ecosystem and because annual crops produce less root biomass than perennial grasses (Burke et al. 1995). Management practices that stabilize soil properties and 
promote primary production in rangelands are expected to sequester more $\mathrm{C}$ and reduce $\mathrm{CO}_{2}$ emissions.

There is growing interest in converting marginal and eroded cropland in the arid and semi-arid Great Plains into grasslands. If cropland is abandoned, it can take many years for native plant communities to reestablish. Dormaar et al. (1994) found that the vegetation in Stipa-Bouteloua community, cultivated for wheat production for 3 years and then abandoned and grazed, reverted to a community dominated by Stipa comata, with very little Bouteloua gracilis. In the United States, native perennial grasses have been seeded on highly eroded cropland in the Great Plain states under the Conservation Reserve Program (Dunn et al. 1993). In other regions of the Great Plains, cultivated land has been restored or improved by seeding monocultures or mixtures of nonnative perennial grasses (Lawrence and Ratzlaff 1989).

The establishment of permanent cover on formerly cultivated lands can quickly stabilize some soil properties, increasing water retention and reducing the quantities of sediments, nutrients and agrochemicals transported to surface waters within a few years (Dunn et al. 1993). It appears to take much longer for soil chemical and biological properties to recover after cultivation ceases. Dormaar and Smoliak (1985) reported that it took more than 50 years for the soil organic $\mathrm{C}$ content of abandoned cropland to approach the level of native rangeland. Five years after establishment of permanent grass cover, Gebhart et al. (1994) observed a $21 \%$ increase in soil organic $\mathrm{C}$ content in the 5 to $10 \mathrm{~cm}$ soil depth, but there was significantly less organic $\mathrm{C}$ in formerly cultivated land than native grasslands. In the first 10 years after cropland was converted to grassland, Baer et al. (2000) found no change in the total $\mathrm{C}$ and $\mathrm{N}$ pools, but an increase in microbial biomass $\mathrm{C}$ and $\mathrm{N}$ pools. Total $\mathrm{C}$ and $\mathrm{N}$, microbial biomass and mineralization potentials were lower in the recently established grasslands than native grassland (Baer et al. 2000). If we hope to increase $\mathrm{C}$ sequestration on formerly cultivated lands in the Great Plains, we must first understand how cultivation has altered soil chemical and biochemical properties and then determine what management practices will be most effective at building the soil organic $\mathrm{C}$ reserves.

We examined selected soil characteristics at 3 sites along a climatic gradient in the Northern Great Plains. Between 5 and 6 years earlier, native rangeland was cultivated and then 1) abandoned, 2) seeded with non-native perennial grasses or legumes to establish a permanent cover, or 3 ) converted to agricultural land for annual crop production. We hypothesized that the reserves of total $\mathrm{C}, \mathrm{N}$, and $\mathrm{P}$ would decline after cultivation, relative to native rangeland, but the decline would be lower in plots that were abandoned or planted with perennial plants than those plots that were cultivated repeatedly for annual crop production. We also hypothesized that the decline in total $\mathrm{C}, \mathrm{N}$, and $\mathrm{P}$ reserves after cultivation would be greater in the driest, hottest site where decomposition would be more rapid than at the site with more rainfall and cooler soil temperatures. Extractable $\mathrm{N}$ and $\mathrm{P}$ pools were expected to be greater in cultivated soils than soils under permanent cover because we hypothesized that the roots of perennial crops had a greater capacity to remove $\mathrm{N}$ and $\mathrm{P}$ from the soil solution than the roots of annual crops. The objective of this study was to compare selected soil properties of modified plant communities (monocultures of annual agronomic crops, perennial introduced grasses or a perennial introduced legume) with native plant communities in ungrazed, unfertilized rangeland soils along a climatic gradient in the Northern Great Plains.

\section{Materials and Methods}

\section{Site Description}

The study was conducted at 3 sites in southern Alberta, Canada that are repre- sentative of major ecotypes of the Northern Great Plains. The sites were at the Agriculture and Agri-Food Canada Substation at Onefour, the Animal Diseases Research Institute (ADRI) near Lethbridge, and the Agriculture and AgriFood Canada Substation west of Stavely in the Porcupine Hills. Information on the location (latitude/longitude), soil type, native plant community, and annual precipitation of each site is provided in Table 1. We refer to the sites by their native plant communities in this paper.

\section{Experimental Treatments}

In April 1993 (Stipa-BoutelouaAgropyron and Festuca campestris) and April 1994 (Stipa-Bouteloua), 6 experimental treatments representing common production practices were established and compared with the native plant community in a randomized complete block design with 4 replicates. The experimental treatments (Table 2) were established in $3 \times 10$ $m$ plots after cultivating the plots with a moldboard plow and seeding with introduced grasses, alfalfa, or wheat. In the abandoned treatment, the native plant community was cultivated several times during the first summer and volunteer plants that emerged from live tillers were removed until the spring of the second year. The experimental treatments were enclosed with a 4-strand barbed-wire fence that excluded livestock. Native plant communities in the study area and site preparation have been described by Moss and Campbell (1947), Coupland (1961) and Dormaar and Willms (2000a). This study began in the spring of 1999, which was 6 years after the experimental treatments were established at the StipaBouteloua-Agropyron and Festuca campestris sites and 5 years after the experiment began at the Stipa-Bouteloua site.

\section{Soil Analysis}

Soil samples were obtained from the Ah soil horizon ( 0 to $15-\mathrm{cm}$ depth) of plots at the 3 sites in the spring and in the fall after

Table 1. Soil and vegetation characteristics, and mean annual precipitation at the study sites.

\begin{tabular}{|c|c|c|c|c|c|c|}
\hline Site & Location & $\begin{array}{l}\text { Soil Classification } \\
\text { Canada }\end{array}$ & US & $\begin{array}{l}\text { Prairie } \\
\text { Classific }\end{array}$ & Native Vegetation & $\begin{array}{l}\text { Average } \\
\text { Precipitation }\end{array}$ \\
\hline Onefour & $\begin{array}{l}49^{\circ} 07^{\prime} \mathrm{N} \\
110^{\circ} 29^{\prime} \mathrm{W}\end{array}$ & Orthic Brown Chernozem & Aridic Haploboroll & Mixed & Stipa-Bouteloua & $310 \mathrm{~mm}$ \\
\hline ADRI & $\begin{array}{l}49^{\circ} 43^{\prime} \mathrm{N} \\
112^{\circ} 57^{\prime} \mathrm{W}\end{array}$ & Orthic Dark Brown Chernozem & Typic Haploboroll & Mixed & Stipa-Bouteloua-Agropyron & $420 \mathrm{~mm}$ \\
\hline Stavely & $\begin{array}{l}50^{\circ} 12^{\prime} \mathrm{N} \\
113^{\circ} 57^{\prime} \mathrm{W}\end{array}$ & $\begin{array}{l}\text { Orthic Black } \\
\text { Chernozem }\end{array}$ & Udic Haploboroll & Fescue & Festuca campestris & $550 \mathrm{~mm}$ \\
\hline
\end{tabular}


Table 2. Experimental treatments established at the study sites.

\begin{tabular}{|c|c|c|}
\hline \multirow[t]{2}{*}{ Experimental Treatment } & \multicolumn{2}{|c|}{ Species/cultivar } \\
\hline & Stipa-Bouteloua and Stipa-Bouteloua-Agropyron sites & Festuca campestris site \\
\hline Introduced grass \#1 & Crested wheatgrass (Agropyron cristatum L. Gaertn.) & Smooth bromegrass (Bromus inermis Leyss.) \\
\hline Introduced grass \#2 & Russian wildrye (Elymus junceus Fisch.) & Orchard grass (Dactylis glomerata L.) \\
\hline Alfalfa & Medicago sativa L. "Beaver" & \\
\hline Spring wheat (continuous) & Triticum aestivum L. "Katepwa" & \\
\hline Spring wheat/fallow rotation & Triticum aestivum L. "Katepwa" & \\
\hline Abandoned & Native vegetation regrown after cultivation & \\
\hline
\end{tabular}

wheat harvest. In 1999, we collected samples on 12 May and 28 September (StipaBouteloua-Agropyron), 20 May and 29 September (Stipa-Bouteloua) and 26 May and 30 September (Festuca campestris) whereas in 2000 , we collected samples on 28 April (Stipa-Bouteloua-Agropyron), 5 May (Festuca campestris), and 19 May (Stipa-Bouteloua). Ten subsamples were collected from randomly selected locations within each experimental plot with a soil probe $(3.2 \mathrm{~cm}$ internal diameter), composited, sieved $(<2 \mathrm{~mm}$ mesh) and then stored in sealed polyethylene bags at $4^{\circ} \mathrm{C}$ until analysis. Surface soil bulk density was determined in the fall of 1999 after harvest from undisturbed soil cores ( $3 \mathrm{~cm}$ length $\times 5.5 \mathrm{~cm}$ internal diameter) taken at the 0 to $3 \mathrm{~cm}$ depth. Bulk density ( $\mathrm{g}$ oven-dried soil $\mathrm{cm}^{3}$ ) in each core was determined after drying at $105^{\circ} \mathrm{C}$ for 48 hours (Blake and Hartge 1986).

Inorganic $\mathrm{N}$ and extractable $\mathrm{P}$ were measured on field-moist soil samples within 3 weeks of arrival at the laboratory. Soil moisture content was determined gravimetrically $\left(105^{\circ} \mathrm{C}\right.$ for 48 hours $)$ and all concentrations were expressed per gram of dry soil. Inorganic $\mathrm{N}\left(\mathrm{NH}_{4}-\mathrm{N}\right.$ and $\mathrm{NO}_{3}-\mathrm{N}$ ) was determined in $2 \mathrm{M} \mathrm{KCl}$ extracts (1:5 soil:extractant) using the method of Maynard and Kalra (1993) and measured colorimetrically using the phenate and cadmium reduction-diazotization methods with a Technicon II flow-injection autoanalyzer (Technicon Industrial Systems, Tarrytown, N.Y.). Extractable P was determined in Kelowna $(0.015 \mathrm{M}$ $\mathrm{NH}_{4} \mathrm{~F}+0.25 \mathrm{M} \mathrm{CH} \mathrm{CH}_{3} \mathrm{COOH}$ ) soil extracts (1:10 soil:extractant) based on Van Lierop (1988). Ortho-phosphate was measured colorimetrically by the ammonium molybdate-ascorbic acid method (Murphy and Riley 1962) using a Technicon IV flowinjection autoanalyzer (Technicon Industrial Systems, Tarrytown, N.Y.).

A portion of soil collected from each site in the fall of 1999 was oven-dried ( $105^{\circ} \mathrm{C}$ for 48 hours), finely ground, and analyzed for total $\mathrm{C}, \mathrm{N}$, and $\mathrm{P}$. Total $\mathrm{C}$ and $\mathrm{N}$ was determined by combustion with a
Carlo-Erba $\mathrm{CN}$ analyzer (Milano, Italy). Total $\mathrm{P}$ was determined on a 1 -g soil sample that was digested with $\mathrm{H}_{2} \mathrm{SO}_{4}$ and $\mathrm{H}_{2} \mathrm{O}_{2}$ with catalysts $\left(\mathrm{LiSO}_{4}\right.$ and $\mathrm{Se}$ powder) at $360^{\circ} \mathrm{C}$ for 2.5 hours (Parkinson and Allen 1975). Following digestion, the samples were analyzed colorimetrically for ortho-phosphorus using the ammonium molybdate-ascorbic acid method (Murphy and Riley 1962) on a Technicon IV flowinjection autoanalyzer (Technicon Industrial Systems, Tarrytown, N.Y.).

\section{Plant Yields}

Plant yields were measured at peak standing crop (late August to early September) each year from 1998 to 2000 . A $0.25 \mathrm{~m}^{2}$ subplot was harvested from each experimental treatment at a different sampling location each year. Vegetation in the subplot was clipped to ground level using hand clippers and sorted into dead (previous years' production) and live plant biomass. Live plant biomass was ovendried $\left(60^{\circ} \mathrm{C}\right.$ for 48 hours), and the aboveground net primary production (ANPP) was calculated on a $g$ dry matter $\mathrm{m}^{-2}$ basis. The net primary productivity (NPP) was estimated as follows:

$$
\mathrm{NPP}=\mathrm{ANPP}_{\mathrm{m}}+\left(\mathrm{ANPP}_{\mathrm{m}} \times \mathrm{R} / \mathrm{S} \text { ratio }\right) \text { (1) }
$$

where $\mathrm{ANPP}_{\mathrm{m}}$ is the mean aboveground net primary productivity and $R / S$ ratio is the root to shoot ratio used to estimate root production during a growing season.

\section{Statistical Analysis}

Data were evaluated statistically by ANOVA in a general linear model using SAS software (Version 8.02 for Windows, SAS Institute Inc., Cary, N.C., USA). The effects of experimental treatments and sampling time within a site were evaluated with a two-way ANOVA and compared with a protected LSD test at the $95 \%$ confidence level.

\section{Results and Discussion}

Soil bulk density was lower in undisturbed native rangeland than modified plant communities (Table 3 ). The bulk density tended to decline in plots with the same experimental treatment across sites, with Stipa-Bouteloua > Stipa-BoutelouaAgropyron > Festuca campestris. Bulk density declines with increasing soil organic matter content because the quantity of air-filled pore space increases. The relationships between bulk density (BD) and the total soil $\mathrm{C}$ (SC) content $\left(\mathrm{g} \mathrm{C} \mathrm{kg}^{-1}\right)$ were:

$$
\begin{aligned}
& \mathrm{BD}=1.385-0.0295 \mathrm{SC} ; \mathrm{R}^{2}= \\
& 0.51, \mathrm{n}=30 \text { Stipa-Bouteloua } \text { site } \\
& \mathrm{BD}=1.469-0.0216 \mathrm{SC} ; \mathrm{R}^{2}= \\
& 0.65, \mathrm{n}=30 \text { Stipa-Bouteloua- } \\
& \text { Agropyron site } \\
& \mathrm{BD}=1.537-0.0111 \mathrm{SC} ; \\
& \mathrm{R}^{2}=0.53, \mathrm{n}=27 \text { Festuca } \\
& \text { campestris site }
\end{aligned}
$$

Table 3. Soil bulk density ( 0 to $3 \mathrm{~cm}$ depth) under native rangeland and modified plant communities in southern Alberta, Canada. Values are means \pm standard errors.

\begin{tabular}{lccc}
\hline \hline Treatment & Stipa-Bouteloua & Stipa-Bouteloua-Agropyron & Festuca campestris \\
\hline & $-1.79 \pm 0.02$ & $0.51 \pm 0.04$ & $0.39 \pm 0.08$ \\
Native & $0.92 \pm 0.05$ & $0.81 \pm 0.02$ & - \\
Crested wheatgrass & $0.89 \pm 0.06$ & $0.89 \pm 0.02$ & - \\
Russian wildrye & - & - & $0.62 \pm 0.03$ \\
Smooth bromegrass & - & - & $0.59 \pm 0.04$ \\
Orchardgrass & $0.97 \pm 0.05$ & $0.85 \pm 0.02$ & $0.69 \pm 0.04$ \\
Alfalfa & $1.01 \pm 0.05$ & $0.94 \pm 0.03$ & $0.77 \pm 0.02$ \\
Continuous wheat & $1.08 \pm 0.04$ & $0.83 \pm 0.01$ & $0.76 \pm 0.04$ \\
Wheat-fallow & $0.91 \pm 0.06$ & & $0.60 \pm 0.03$ \\
Abandoned & &
\end{tabular}


These relationships are similar to those reported by Bauer and Black (1992) for cropped agroecosystems, grazed, and relict grasslands in North Dakota. The slopes of the regression lines between BD and soil organic $\mathrm{C}$ ranged from -0.0128 to -0.0212 , depending on soil texture (Bauer and Black 1992).

\section{Total $C, N$, and $P$ in soils}

The total $\mathrm{C}, \mathrm{N}$, and $\mathrm{P}$ content of rangeland soils decline upon cultivation and it may take many years for soil nutrient pools to return to pre-cultivation levels (Dormaar and Smoliak 1985). To determine whether net gains or losses of total $\mathrm{C}, \mathrm{N}$, and $\mathrm{P}$ have occurred in the soil profile on a $\mathrm{kg} \mathrm{ha}^{-1}$ basis, it is necessary to collect soil samples to perhaps a $2-\mathrm{m}$ depth and determine the nutrient content and bulk density of each soil layer sampled (Lal 2002). Since we did not collect this information, our discussion will focus on differences in the total and available nutrient contents ( $\mathrm{g} \mathrm{kg}^{-1}$ soil basis) in the 0 to $15 \mathrm{~cm}$ layer of soils under native rangeland and modified plant communities.

Total $\mathrm{C}$ and $\mathrm{N}$ were significantly lower in soils under modified plant communities than native rangeland at the StipaBouteloua and Stipa-BoutelouaAgropyron sites, with the lowest total C and $\mathrm{N}$ contents in the continuous wheat and wheat-fallow treatments (Table 4). Soils under alfalfa had higher total $\mathrm{C}$ and $\mathrm{N}$ than the abandoned, continuous wheat, and wheat-fallow treatments at the StipaBouteloua site, and a higher total C and N than the wheat-fallow treatment at the Stipa-Bouteloua-Agropyron site) (Table 4). Alfalfa can fix $\mathrm{N}_{2}$ from the atmosphere, and this external input of $\mathrm{N}$ could contribute to a higher soil $\mathrm{N}$ content under alfalfa than some other treatments at the Stipa-Bouteloua and Stipa-BoutelouaAgropyron sites. The higher soil C content in the alfalfa treatment than some modified plant communities was unexpected because our estimates suggest a lower NPP for alfalfa than most other plant communities (Table 5). The stabilization of $\mathrm{C}$ in soils is a complex process that depends on the activity of decomposers, primarily soil microorganisms. In most modified plant communities, microbial growth and biomass production may have been limited by $\mathrm{N}$ availability since no $\mathrm{N}$ fertilizers were added, but this was probably not the case in the alfalfa treatment. Nitrogen fixation in the alfalfa treatment could cause an increase in the microbial biomass, leading to greater microbial activity and the production of $\mathrm{C}$-containing compounds that become stabilized in soils (dead microbial cells, polysaccharides and other byproducts of microbial metabolism). Moore et al. (2000) found that microbial biomass $\mathrm{C}$ and $\mathrm{N}$ concentrations were greater in soil under alfalfa than soils under continuous corn or continuous soybean production. They attributed these differences to the type and quantity of organic compounds released into the soil. Alfalfa residues (above-ground litter and dead roots) appeared to degrade more quickly than corn or soybean residues in the cropping systems examined. We would need to measure soil microbial biomass $\mathrm{C}$ and $\mathrm{N}$ pools and residue decomposition rates to determine whether these factors could explain differences in the soil $\mathrm{C}$ content of modified plant communities at the Stipa-Bouteloua and StipaBouteloua-Agropyron sites.

The decline in total $\mathrm{C}$ and $\mathrm{N}$ in the wheat-fallow rotation compared to alfalfa was expected because the fallow phase of the rotation contributes little $\mathrm{C}$ through primary production and is cultivated, disrupting soil aggregates and accelerating $\mathrm{C}$ and N mineralization (Elliott 1986, Paustian et al. 1997). Soils under continuous wheat had less total $\mathrm{C}$ and $\mathrm{N}$ than soils under alfalfa at the Stipa-Bouteloua site, and less total $\mathrm{N}$ than soils under alfalfa at the Stipa-Bouteloua-Agropyron site.
Although the net primary production (NPP) of the continuous wheat was similar to the NPP of alfalfa at the StipaBouteloua site (Table 5), the net $\mathrm{C}$ input ( $\mathrm{C}$ added in plant residues minus $\mathrm{CO}_{2}-\mathrm{C}$ lost) from continuous wheat was probably lower than alfalfa because 35 to $45 \%$ of the above-ground biomass is removed when grain is harvested (Paustian et al. 1997). At the Stipa-Bouteloua-Agropyron site, there was no difference in total $C$ from soils under continuous wheat or alfalfa, but the NPP of wheat was more than double the NPP of alfalfa (Tables 4 and 5). It was difficult to get an accurate estimate of ANPP in the alfalfa and wheat treatments at the Stipa-BoutelouaAgropyron site because deer and rodents consumed some of the above-ground biomass before plant yields were taken. Better estimates of the NPP could improve our understanding of soil $\mathrm{C}$ dynamics at the Stipa-Bouteloua-Agropyron site.

At the Festuca campestris site, soils under native rangeland and orchardgrass had generally higher total $\mathrm{C}$ and $\mathrm{N}$ than other monoculture grass or cultivated treatments (Table 4). The total $\mathrm{C}$ and $\mathrm{N}$ content of soils under orchardgrass were similar to native rangeland 6 years after the modified plant community was established, which suggests that orchardgrass can increase the soil $\mathrm{C}$ and $\mathrm{N}$ content much more rapidly than the other perennial communities investigated. There tended to be more NPP and total C in soils under orchardgrass than other modified plant communities, suggesting a higher net $\mathrm{C}$ input into soils from orchardgrass (Tables 4 and 5). Orchardgrass has a higher rootto-shoot ratio than the native Festuca campestris vegetation or other modified plant communities (Table 5), and we propose that root production and turnover was responsible for the increase in soil $\mathrm{C}$ content under orchardgrass. We are not aware of other studies that show a more rapid increase in soil $\mathrm{C}$ pools under orchard-

Table 4. Total $\mathbf{C}, \mathbf{N}$, and $\mathbf{P}$ in soils under native rangeland and modified plant communities in southern Alberta, Canada.

\begin{tabular}{|c|c|c|c|c|c|c|c|c|c|}
\hline \multirow[t]{2}{*}{ Treatment } & \multicolumn{2}{|l|}{ Stipa-Bouteloua } & \multicolumn{3}{|c|}{ Stipa-Bouteloua-Agropyron } & \multicolumn{2}{|c|}{ Festuca campestris } & \multirow[b]{2}{*}{$\left(\mathrm{g} \mathrm{N} \mathrm{kg}^{-1}\right)$} & \multirow[b]{2}{*}{$\left(\mathrm{mg} \mathrm{P} \mathrm{kg}{ }^{-1}\right)$} \\
\hline & $\left(\mathrm{g} \mathrm{C} \mathrm{kg}^{-1}\right)$ & $\left(\mathrm{g} \mathrm{N} \mathrm{kg}^{-1}\right)$ & $\left(\mathrm{mg} \mathrm{P} \mathrm{kg}^{-1}\right)$ & $\left(\mathrm{g} \mathrm{C} \mathrm{kg}^{-1}\right)$ & $\left(\mathrm{g} \mathrm{N} \mathrm{kg}^{-1}\right)$ & $\left(\mathrm{mg} \mathrm{P} \mathrm{kg}^{-1}\right)$ & $\left(\mathrm{g} \mathrm{C} \mathrm{kg}^{-1}\right)$ & & \\
\hline Native & 21.6 & 2.08 & 346 & 42.4 & 4.00 & 575 & 101.4 & 8.70 & 907 \\
\hline Crested wheatgrass & 15.1 & 1.58 & 330 & 29.1 & 2.90 & 528 & - & - & - \\
\hline Russian wildrye & 14.8 & 1.55 & 326 & 28.0 & 2.81 & 524 & - & - & - \\
\hline Smooth bromegrass & - & - & - & - & - & - & 84.2 & 7.44 & 959 \\
\hline Orchardgrass & - & - & - & - & - & - & 96.6 & 8.27 & 981 \\
\hline Alfalfa & 15.8 & 1.70 & 333 & 29.7 & 3.03 & 521 & 83.8 & 7.35 & 889 \\
\hline Continuous wheat & 13.1 & 1.45 & 328 & 26.4 & 2.72 & 519 & 71.1 & 6.18 & 872 \\
\hline Wheat-fallow & 13.3 & 1.43 & 318 & 25.5 & 2.70 & 521 & 80.5 & 7.00 & 928 \\
\hline Abandoned & 13.9 & 1.50 & 315 & 29.1 & 2.93 & 538 & 81.3 & 7.15 & 910 \\
\hline $\operatorname{LSD}(\mathrm{P}<0.05)$ & 1.9 & 0.18 & 26 & 3.6 & 0.27 & 22 & 10.5 & 0.93 & 93 \\
\hline
\end{tabular}


grass than other plant communities, and further work is needed to confirm our findings.

Soils of the continuous wheat treatment at the Festuca campestris site had less total $\mathrm{C}$ than the orchardgrass, bromegrass and alfalfa treatments, and less total $\mathrm{N}$ than the orchardgrass, bromegrass, alfalfa and abandoned treatments (Table 4). However, only soils under orchardgrass had more total $\mathrm{C}$ and $\mathrm{N}$ than soils under the wheat-fallow treatment (Table 4). These results suggest that more $\mathrm{C}$ and $\mathrm{N}$ export occurred in the continuous wheat treatment, where grain was harvested and removed from the plots each year, than the wheat-fallow treatment. Weed biomass produced during the fallow phase was incorporated into the soil before the wheat crop was planted, which would add $\mathrm{C}$ and recycle the $\mathrm{N}$ taken up by weeds. Although differences in the total $\mathrm{C}$ and $\mathrm{N}$ content of soils may be related to differences in the NPP of continuous wheat and wheat-fallow treatments, it was difficult to obtain good estimates of NPP for these treatments. Yields (mean \pm standard error) in the continuous wheat treatment were $199 \pm 33 \mathrm{~g} \mathrm{~m}^{-2}$ in $1998,830 \pm 77 \mathrm{~g} \mathrm{~m}^{-1}$ in 1999 and $108 \pm 17 \mathrm{~g} \mathrm{~m}^{-1}$ in 2000 , which led to considerable variability in the mean ANPP values in the continuous wheat and wheat-fallow treatments (Table 5). Our findings suggests a higher net $\mathrm{C}$ input into soils under wheat-fallow than continuous wheat at the Festuca campestris site, but better above-ground biomass measurements are needed to confirm this possibility.

The total $\mathbf{P}$ content of soils varied little among experimental treatments. The total $P$ content of soil was significantly higher in native rangeland than monoculture grass or cultivated treatments at the Stipa-
Bouteloua-Agropyron site, but there was no difference in the total $P$ content of native rangeland and most modified plant communities at the Stipa-Bouteloua and Festuca campestris sites (Table 4). Only a small proportion of the total $\mathrm{P}$ in soils is used for primary production, and it is recycled when plant residues are not exported from the site. Above-ground wheat biomass contains about $0.5 \%$ total $P$ (Heyne 1987), and if grain was $45 \%$ of the above-ground biomass, then 4 to $9 \mathrm{~kg} \mathrm{P}$ $\mathrm{ha}^{-1}$ would be removed from the continuous wheat and wheat-fallow treatments at harvest. This estimate is consistent with Campbell et al. (1997), who estimated 5.5 to $11.6 \mathrm{~kg} \mathrm{P} \mathrm{ha}^{-1}$ year $^{-1}$ was exported in grain and hay from crop rotations in Saskatchewan. The few differences that emerged among experimental treatments are probably related to $\mathrm{P}$ removed in roots and soil when the sites were initially cultivated and raked (Dormaar and Willms 2000b). This finding is consistent with results from Elliott (1986), which showed that aggregate fractions contained less $\mathrm{C}$, $\mathrm{N}$ and $\mathrm{P}$ when soils were cultivated than when they were left under native sod, but $\mathrm{C}$ and $\mathrm{N}$ losses from cultivated soils were much greater than $\mathrm{P}$ losses.

Although the loss of total $\mathrm{C}$ and $\mathrm{N}$ in soils under the same experimental treatments, relative to native rangeland, was similar at the Stipa-Bouteloua and StipaBouteloua-Agropyron sites, much less total $\mathrm{C}$ and $\mathrm{N}$ was lost from soils at the Festuca campestris site. For instance, soils under continuous wheat contained between 38 and $39 \%$ less total $C$ than native rangeland at the Stipa-Bouteloua and Stipa-Bouteloua-Agropyron sites, but only $28 \%$ less total $\mathrm{C}$ than native rangeland at the Festuca campestris site. These findings support our hypothesis that proportionately more $\mathrm{C}$ and $\mathrm{N}$ would be lost from the Stipa-Bouteloua and StipaBouteloua-Agropyron sites than the Festuca campestris site due to climatic conditions (rainfall and temperature). Dormaar and Willms (1993) found that roots from blue grama and rough fescue grasses decomposed more rapidly at the Stipa-Bouteloua site than the Festuca campestris site. They proposed that greater fluctuations in soil temperature and moisture at the Stipa-Bouteloua site than the Festuca campestris site contributed to physical comminution of roots, exposing a larger surface area for microbial colonization and decomposition. Fluctuations in soil temperature and moisture, particularly those associated with wet-dry and freezethaw cycles, may also accelerate the breakdown and decomposition of surface litter and destabilize soil aggregates, increasing $\mathrm{C}$ and $\mathrm{N}$ mineralization (Paustian et al. 1997).

The similarity in total $\mathrm{C}$ and $\mathrm{N}$ of soils under orchardgrass and native rangeland at the Festuca campestris site supports our hypothesis that recovery of total $\mathrm{C}$ and $\mathrm{N}$ in soils under permanent cover would occur more quickly at this site because it receives more rainfall and has cooler soil temperatures than the Stipa-Bouteloua and Stipa-Bouteloua-Agropyron sites. In ungrazed prairies, the restoration of total $C$ and $\mathrm{N}$ in soils under introduced grasses to the levels found in native rangeland also depends on the net $\mathrm{C}$ and $\mathrm{N}$ inputs from plant litter (above- and below-ground biomass), which may not be directly related to NPP. Lutwick and Dormaar (1976) found that soil $(0-15 \mathrm{~cm}$ depth) under blue grama contained $25 \mathrm{~g} \mathrm{C} \mathrm{kg}^{-1}$ whereas soil under rough fescue contained $111 \mathrm{~g} \mathrm{C} \mathrm{kg}^{-1}$,

Table 5. Mean annual aboveground net primary productivity (ANPP), the root to shoot (R:S) ratio, and the estimated net primary productivity (NPP) in native rangeland and modified plant communities in southern Alberta, Canada.

\begin{tabular}{|c|c|c|c|c|c|c|c|c|c|}
\hline \multirow[t]{2}{*}{ Treatment } & \multicolumn{2}{|l|}{ Stipa-Bouteloua } & \multicolumn{3}{|c|}{ Stipa-Bouteloua-Agropyron } & \multicolumn{3}{|c|}{ Festuca campestris } & \multirow[b]{2}{*}{ NPP } \\
\hline & $\mathrm{ANPP}^{1}$ & $\mathrm{R}: \mathrm{S}$ ratio $^{2}$ & NPP & ANPP & $\mathrm{R}: \mathrm{S}$ ratio & NPP & ANPP & $\mathrm{R}: \mathrm{S}$ ratio & \\
\hline & $\left(\mathrm{g} \mathrm{m}^{-2}\right)$ & & $\left(\mathrm{g} \mathrm{m}^{-2}\right)$ & $\left(\mathrm{g} \mathrm{m}^{-2}\right)$ & & $\left(\mathrm{g} \mathrm{m}^{-2}\right)$ & $\left(\mathrm{g} \mathrm{m}^{-2}\right)$ & & $\left(\mathrm{g} \mathrm{m}^{-2}\right)$ \\
\hline Native & $108 \pm 18$ & 8.7 & 1048 & $218 \pm 30$ & 8.7 & 2115 & $354 \pm 42$ & 4.0 & 1456 \\
\hline Crested wheatgrass & $206 \pm 26$ & 6.7 & 1586 & $197 \pm 23$ & 6.7 & 1517 & - & - & - \\
\hline Russian wildrye & $170 \pm 15$ & 15.1 & 2737 & $97 \pm 13$ & 15.1 & 1563 & - & - & - \\
\hline Smooth bromegrass & - & - & - & - & - & - & $280 \pm 25$ & 2.9 & 1092 \\
\hline Orchardgrass & - & - & - & - & - & - & $196 \pm 18$ & 7.6 & 1686 \\
\hline Alfalfa & $142 \pm 37$ & 0.5 & 213 & $77 \pm 18$ & 0.5 & 116 & $335 \pm 55$ & 0.5 & 503 \\
\hline Continuous wheat & $195 \pm 39$ & 0.2 & 234 & $258 \pm 57$ & 0.2 & 310 & $379 \pm 100$ & 0.2 & 455 \\
\hline Wheat-fallow & $186 \pm 73$ & 0.2 & 223 & $95 \pm 45$ & 0.2 & 114 & $419 \pm 161$ & 0.2 & 503 \\
\hline Abandoned & $160 \pm 38$ & 3.1 & 656 & $259 \pm 26$ & 3.1 & 1062 & $291 \pm 34$ & 4.0 & 1455 \\
\hline
\end{tabular}

${ }^{\mathrm{T}}$ Values are the means ( \pm standard error) of ANPP ( $\mathrm{g}$ dry matter $\mathrm{m}^{-2}$ ) from 1998-2000 except the wheat-fallow treatment (mean \pm standard error of ANPP from 1998-1999)

${ }^{2}$ Root:shoot (R:S) ratios from the following sources: native/abandoned Stipa-Bouteloua/Stipa-Bouteloua-Agropyron rangeland (Dormaar and Smoliak 1985), native/abandoned Festuca campestris rangeland (J.F. Dormaar, personal communication), crested wheatgrass and Russian wildrye (Willms et al. 2001), smooth bromegrass and orchardgrass (W.D. Willms, personal communication), alfalfa (Mapfumo et al. 1998), and wheat (Heyne 1987). 
despite similar root biomass production. The net $C$ input to soils is affected by the rate of decomposition of plant residues, and for the roots of rangeland plants, has been shown to depend on the $\mathrm{C}: \mathrm{N}$ ratio, lignin and carbohydrate content of the residue (Herman et al. 1977). Further work is needed to verify the quantity and chemical composition of plant shoots and roots that enters the soils from modified plant communities to determine what proportions of $\mathrm{C}$ and $\mathrm{N}$ in plant litter are stabilized or lost from soils.

\section{Extractable $\mathbf{N}$ and $\mathbf{P}$ in soils}

We hypothesized that tillage would stimulate $\mathrm{N}$ and $\mathrm{P}$ mineralization, and therefore extractable $\mathrm{N}$ and $\mathrm{P}$ concentrations would be greater in cultivated soils than soils under perennial plant communities. At the 3 sites examined, the inorganic $\mathrm{N}$ pool was larger in soils of the 2 cultivated treatments (continuous wheat and wheat-fallow) than in soils under introduced grass monocultures at nearly all sampling dates (Fig. 1). There was more inorganic $\mathrm{N}$ in soils under alfalfa than introduced grass monocultures at most sampling dates in the Stipa-Bouteloua and Stipa-Bouteloua-Agropyron sites, possibly because some of the $\mathrm{N}_{2}$ fixed by the alfalfa was released into the soil solution during normal plant development or at senescence (Simpson 1976). Although soils under native rangeland tended to have lower inorganic $\mathrm{N}$ concentrations than cultivated soils, they had similar inorganic $\mathrm{N}$ concentrations as soils under the introduced grasses (Fig. 1). There are 2 possible explanations for this finding. One possibility is that introduced grasses and the plant communities of native rangelands absorb more inorganic $\mathrm{N}$ from soil solution than alfalfa or wheat. The fibrous root systems of introduced grasses and native plant communities could make them quite efficient at intercepting and absorbing $\mathrm{NH}_{4}-\mathrm{N}$ and $\mathrm{NO}_{3}-\mathrm{N}$ from the soil solution. The other possibility is that $\mathrm{N}$ immobilization by microbial biomass was higher in treatments with introduced grasses and native plant communities than alfalfa or wheat. Measurements of $\mathrm{N}$ uptake by different plant species and $\mathrm{N}$ immobilization by microorganisms under native and modified plant communities are needed to understand our results. Inorganic $\mathrm{N}$ that is not used by plants or soil organisms could be lost to the environment in leachates, surface runoff and gaseous products. We expect that $\mathrm{N}$ losses would be highest from the continuous wheat and wheat-fallow treatments, followed by the alfalfa
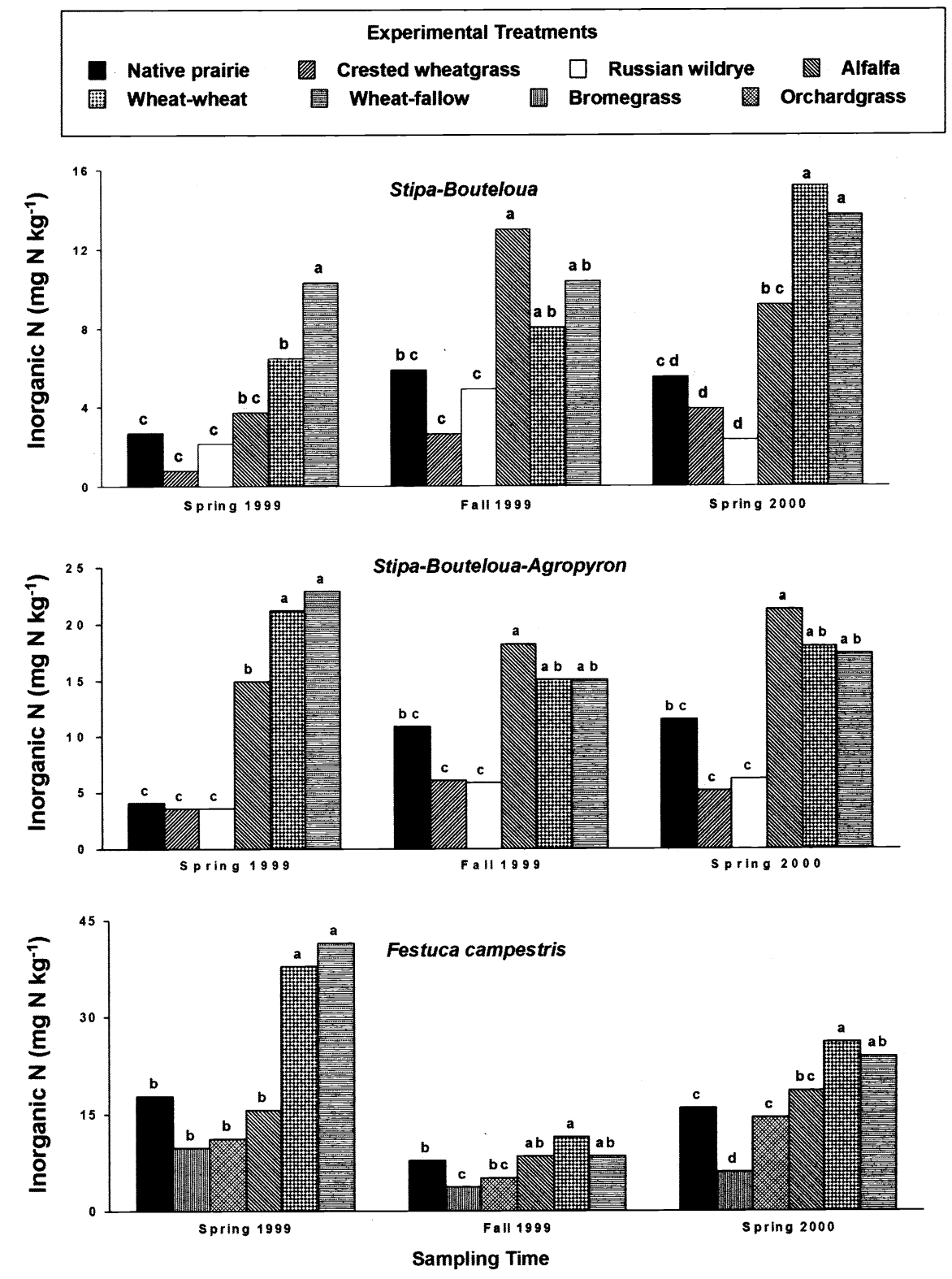

Fig. 1. Inorganic $\mathrm{N}\left(\mathrm{NH}_{4}-\mathrm{N}\right.$ plus $\left.\mathrm{NO}_{3}-\mathrm{N}\right)$ concentrations in soils under native rangeland and modified plant communities at sites dominated by Stipa-Bouteloua, Stipa-BoutelouaAgropyron and Festuca campestris vegetation. At each sampling date, mean values with the same letter are not significantly different at $P<0.05$ (protected LSD test).

treatment, and lowest from native rangeland and the introduced grass treatments. Further work would be needed to quantify $\mathrm{N}$ losses from native rangeland and modified plant communities.

Extractable $\mathrm{P}$ concentrations in soils at the Stipa-Bouteloua and Stipa-BoutelouaAgropyron sites did not vary among treatments, although the extractable $\mathrm{P}$ levels tended to be greater in the fall than spring samples (Fig. 2). Higher extractable P levels suggest that more $P$ is present in forms available for plant uptake in the fall than spring, which may be due to rapid uptake of plant-available $P$ in the spring that depletes the extractable $P$ reserves (Dormaar 1972). Plant-available P may originate from organic $\mathrm{P}$ compounds, and the potential activity of phosphatases responsible for $\mathrm{P}$ mineralization in the Mixed and Fescue Prairies peaks in February and declines in the early spring, possibly due to enzyme deactivation during spring thaw (Dormaar et al. 1984). Phosphatase activity measured by Dormaar and Willms (2000a) in the modified plant communities at the Stipa-Bouteloua and Stipa-Bouteloua-Agropyron sites tended to 

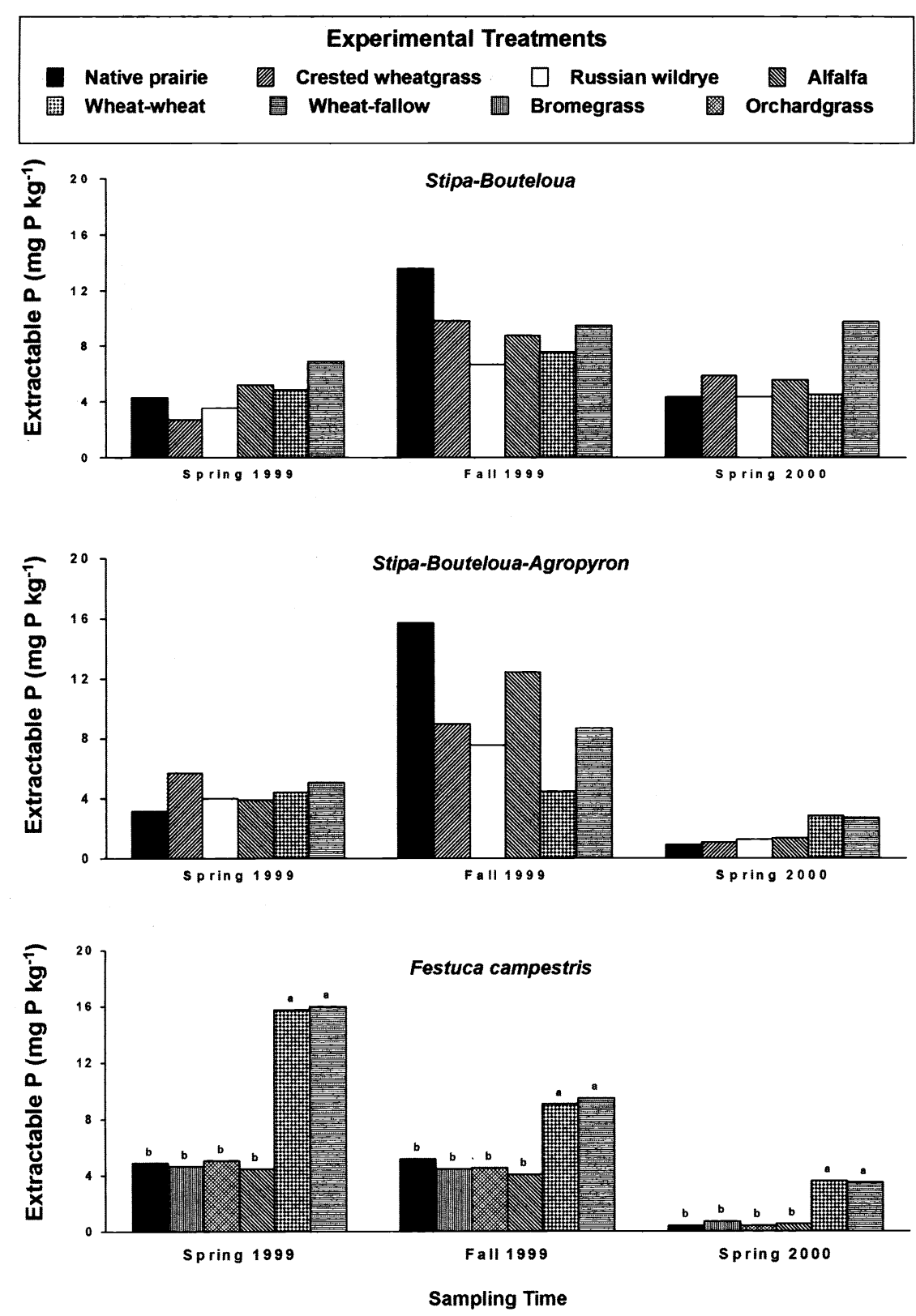

Fig. 2. Extractable $P$ concentrations in soils under native rangeland and modified plant communities at a site dominated by Stipa-Bouteloua, Stipa-Bouteloua-Agropyron and Festuca campestris vegetation. At the Stipa-Bouteloua and Stipa-Bouteloua-Agropyron sites, there was no difference among treatments at each sampling date. At the Festuca campestris site, mean values with the same letter at each sampling date are not significantly different at $P$ $<0.05$ (protected LSD test).

be lower in the spring than the fall, which could explain the seasonal variation we observed in extractable $P$ concentrations (Fig. 2). Plant-available P may also come from the dissolution of mineral-associated $\mathrm{P}$ complexes by organic acids (Bolan et al. 1994), and investigations are needed to determine whether the concentrations of organic acids capable of solubilizing mineral-associated $\mathrm{P}$ vary seasonally.

At the Festuca campestris site, there ing for $\mathrm{P}$ sorption sites, dissolving precipitated $P$ compounds, altering surface charge, or forming organo-mineral complexes with $\mathrm{Al}, \mathrm{Fe}$, and $\mathrm{Ca}$ (Traina et al. 1986, Iyamuremye and Dick 1996, Ohno and Crannell 1996). This effect was not observed in cultivated soils at the other 2 sites, probably due to differences in soil chemical and environmental conditions. Further research on the $\mathrm{P}$ dynamics of soils from the three sites will be required to explain the differences observed.

\section{Conclusions}

We conclude that production of annual agricultural crops on rangelands in tilled systems can deplete soil $\mathrm{C}$ and $\mathrm{N}$ reserves significantly. The establishment of perennial grasses or legumes on formerly cultivated land can slow, or reverse, the depletion of soil $\mathrm{C}$ and $\mathrm{N}$ reserves. The stabilization or loss of soil $\mathrm{C}$ and $\mathrm{N}$ from modified plant communities is affected by climate (soil temperature and moisture) as well as the quantity and chemical characteristics of residues produced by plants. Differences in the total P content of soils under modified plant communities and native rangeland appeared to be related to the initial site preparation rather than experimental treatments or environmental factors.

\section{Literature Cited}

Anderson, D.W. and D.C. Coleman. 1985. The dynamics of organic matter in grassland soils. J. Soil Water Conserv. 40:211-216.

Baer, S.G., C.W. Rice, and J.M. Blair. 2000. Assessment of soil quality in fields with short and long term enrollment in the CRP. J. Soil Water Conserv. 55:142-146.

Bauer, A. and A.L. Black. 1992. Organic carbon effects on available water capacity of three soil textural groups. Soil Sci. Soc. Amer. J. 56:248-254.

Blake, G.R. and K.H. Hartge. 1986. Bulk density, p. 363-375. In: A. Klute (ed) Methods of soil analysis, Part 1: Physical and mineralogical methods. Agron. Series No. 9, $2^{\text {nd }}$ ed. ASA-CSSA-SSSA, Madison, Wisc.

Bolan, N.S., R. Naidu, S. Mahimairaja, and S. Baskaran. 1994. Influence of low-molecular-weight organic acids on the solubilization of phosphates. Biol. Fertil. Soils 18:311-319.

Burke, I.C., W.K. Lauenroth, and D.P. Coffin. 1995. Soil organic matter recovery in semiarid grasslands: implications for the conservation reserve program. Ecol. Appl. 5:793-801.

Campbell, C.A., G.P. Lafond, A.P. Moulin, 
L. Townley-Smith, and R.P. Zentner. 1997. Crop production and soil organic matter in long-term crop rotations in the subhumid northern Great Plains of Canada, p. 297-315. In: E.A. Paul, K. Paustian, E.T. Elliott, and C.V. Cole (eds) Soil organic matter in temperate agroecosystems: long-term experiments in North America. CRC Press, Boca Raton, Fla.

Coupland, R.T. 1961. A reconsideration of grassland classification in the northern Great Plains of North America. J. Ecol. 49:135-167.

Dormaar, J.F. 1972. Seasonal pattern of soil organic phosphorus. Can. J. Soil Sci. 52:107-112.

Dormaar, J.F. and S. Smoliak. 1985. Recovery of vegetative cover and soil organic matter during revegetation of abandoned farmland in a semiarid climate. J. Range Manage. 38:487-491.

Dormaar, J.F. and W.D. Willms. 1993. Decomposition of blue grama and rough fescue roots in prairie soils. J. Range Manage. 46:207-213.

Dormaar, J.F. and W.D. Willms. 2000a. Rangeland management impacts on soil biological indicators in southern Alberta. J. Range Manage. 53:233-238.

Dormaar, J.F. and W.D. Willms. 2000b. A comparison of soil chemical characteristics in modified rangeland communities. J. Range Manage. 53:453-458.

Dormaar, J.F., B.W. Adams, and W.D. Willms. 1994. Effect of grazing and abandoned cultivation on a Stipa-Bouteloua community. J. Range Manage. 47:28-32.

Dormaar, J.F., A. Johnston, and S. Smoliak. 1984. Seasonal changes in carbon content, and dehydrogenase, phosphatase, and urease activities in mixed prairied and fescue grassland Ah horizons. J. Range Manage. 37:31-35.

Dunn, C.P., F. Stearns, G.R. Guntenspergen, and D.M. Sharpe. 1993. Ecological benefits of the Conservation Reserve Program. J. Soil Water Conserv. 47:132-139.
Elliott, E.T. 1986. Aggregate structure and carbon, nitrogen and phosphorus in native and cultivated soils. Soil Sci. Soc. Amer. J. 50:627-633.

Gebhart, D.L., H.B. Johnson, H.S. Mayeux, and H.W. Polly. 1994. The CRP increases soil organic carbon. J. Soil Water Conserv. 49:488-492.

Herman, W.A., W.B. McGill, and J.F. Dormaar. 1977. Effects of initial chemical composition on decomposition of roots of three grass species. Can. J. Soil Sci. 57:205-215.

Heyne, E.G. 1987. Wheat and wheat improvement. Agron. Monograph No. $13,2^{\text {nd }}$ ed ASA-CSSA-SSSA, Madison, Wisc.

Iyamuremye, F. and R.P. Dick. 1996. Organic amendments and phosphorus sorption by soils. Adv. Agron. 56:139-185.

Lal, R. 2002. Soil carbon dynamics in cropland and rangeland. Environ. Poll. 116:353-362.

Lawrence, T. and C.D. Ratzlaff. 1989. Performance of some native and introduced grasses in a semiarid region of western Canada. Can. J. Plant Sci. 69:251-254.

Lutwick, L.E. and J.F. Dormaar. 1976. Relationships between the nature of soil organic matter and root lignins of grasses in a zonal sequence of Chernozemic soils. Can. J. Soil Sci. 56:363-371.

Mapfumo, E., D.S. Chanasyk, M.A. Naeth, and V.S. Baron. 1998. Forage growth and yield components as influenced by subsurface compaction. Agron. J. 90:805-812.

Maynard, D.G. and Y.P. Kalra. 1993. Nitrate and exchangeable ammonium nitrogen, $\mathrm{p}$. 25-38. In: M.R. Carter (ed) Soil sampling and methods of analysis. Lewis Publishers, Boca Raton, Fla.

Moss, E.G. and J.A. Campbell. 1947. The fescue grassland of Alberta. Can J. Res. C25:209-227.

Moore, J.M., S. Klose, and M.A. Tabatabai. 2000. Soil microbial biomass carbon and nitrogen as affected by cropping system. Biol. Fertil. Soils 31:200-210.

Murphy, J.H. and J.P. Riley. 1962. A modified single solution method for the determination of phosphorous in natural waters. Anal. Chim. Acta. 27:31-36.
Ohno, T. and B.S. Crannell. 1996. Green and animal manure-derived dissolved organic matter effects on phosphorus sorption. J. Environ. Qual. 25:1137-1143.

Parkinson, J.A. and S.E. Allen. 1975. A wet oxidation procedure suitable for the determination of nitrogen and mineral nutrients in biological material. Commun. Soil Sci. Plant Anal. 6:1-11.

Paustian, K., H.P. Collins, and E.A. Paul. 1997. Management controls on soil carbon, p.15-49. In: E.A. Paul, K. Paustian, E.T. Elliott, and C.V. Cole (eds) Soil organic matter in temperate agroecosystems: long-term experiments in North America. CRC Press, Boca Raton, Fla.

Schuman, G.E., H.H. Janzen, and J.E. Herrick. 2002. Soil carbon dynamics and potential carbon sequestration by rangelands. Environ. Poll. 116:391-396.

Simpson, J.R. 1976. Transfer of nitrogen from three pasture legumes under periodic defoliation in a field environment. Aust. J. Exp. Agric. Anim. Husb. 16:863-871.

Traina, S.J., G. Sposito, D. Hesterberg, and U. Kafkafi. 1986. Effects of $\mathrm{pH}$ and organic acids on orthophosphate solubility in an acidic montmorillonitic soil. Soil Sci. Soc. Am. J. 50:45-52.

Van Lierop, W. 1988. Determination of available phosphorus in acid and calcareous soils with the Kelowna multiple-element extractant. Soil Sci. 146:284-291.

Willms, W.D., B.H. Ellert, and J.F. Dormaar. 2001. Evaluation of native plants for reclamation and production. Alberta Agriculture Research Institute Report, Project \#95M813, Lethbridge, Alberta, Canada. 